\title{
Development and evaluation of physico-chemical stability of cosmetic formulations employing the fruits of the Jussara palm tree (Euterpe edulis Martius): tinting shampoo and exfoliant cream
}

\author{
Desenvolvimento e avaliação da estabilidade fisico-química de formulações cosméticas utilizando \\ os frutos da palmeira Jussara (Euterpe edulis Martius): shampoo matizante e creme esfoliante \\ Henriette Marcondes Fonseca de Marcos ${ }^{1}$, Laura Isabella Lopes Favaro ${ }^{1}$, Lilian Katsue Harada ${ }^{1}$, \\ Matthieu Tubino ${ }^{2}$, Valquíria Miwa Hanai Yoshida ${ }^{1}$, Victor Manuel Balcão ${ }^{1,3}$, Marta Maria Duarte \\ Carvalho Vila ${ }^{1}$
}

${ }^{1}$ PhageLab - Laboratory of Biofilms and Bacteriophages, University of Sorocaba, 18023-000 Sorocaba/SP, Brazil; ${ }^{2}$ Institute of Chemistry, State University of Campinas, Campinas/SP, Brazil; ${ }^{3}$ Department of Biology and CESAM, University of Aveiro, Campus Universitário de Santiago, 3810-193 Aveiro, Portugal

*Corresponding author:marta.vila@prof.uniso.br

\begin{abstract}
The major goal of this research work was to use the dry extract of the fruits of Jussara palm tree (Euterpe edulis Martius) in the development of a tinting shampoo $(0.3 \%(\mathrm{w} / \mathrm{v})$ anthocyanin extract) and an exfoliating beauty cream integrating granules from the seeds of the fruit $(1 \%, \mathrm{w} / \mathrm{v})$. The dry extract was characterized via determination of the content of anthocyanins by the differential $\mathrm{pH}$ method, antioxidant activity by the phospho-molybdenum complex methodology, and antimicrobial activity by the disc-diffusion method. The extraction yield was $2.3 \%(\mathrm{w} / \mathrm{w})(2.25 \mathrm{~g}$ dry extract/100 g fruit), with an antioxidant activity of $139.0 \pm 5.5 \%$ relative to that of ascorbic acid, indicating a high antioxidant capacity. The anthocyanin extract did not exhibit antimicrobial activity. The physico-chemical stability characteristics of both the tinting shampoo and the exfoliating cream were evaluated via accelerated stability studies at $0,30,60$ and 90 days of storage at $40 \pm 2{ }^{\circ} \mathrm{C}$ and $75 \pm 5 \%$ relative humidity. The cosmetic products prepared were stable in relation to the physico-chemical characteristics under the conditions studied.
\end{abstract}

Keywords:Jussara; Euterpe edulis Martius; anthocyanins; tinting shampoo; exfoliating cream

\begin{abstract}
Resumo
O principal objetivo deste trabalho de investigação consistiu em utilizar o extrato seco dos frutos da palmeira Jussara (Euterpe edulis Martius) no desenvolvimento de um shampoo matizante $(0,3 \%(\mathrm{~m} / \mathrm{v})$ de extrato antocianínico) e de um creme de beleza esfoliante integrando grânulos das sementes do fruto $(1 \%, \mathrm{~m} / \mathrm{v})$. O extrato seco foi caracterizado através da determinação do teor em antocianinas pelo método do $\mathrm{pH}$ diferencial, a atividade antioxidante pelo método do complexo fosfo-molibdénio e a atividade antimicrobiana pelo método de disco-difusão. O rendimento de extração foi de $2,3 \%(\mathrm{~m} / \mathrm{m})(2,25 \mathrm{~g}$ extrato seco/100 g fruto), com uma atividade antioxidante de $139,0 \pm 5,5 \%$ relativamente àquela do ácido ascórbico, indicando uma alta capacidade antioxidante. $\mathrm{O}$ extrato antocianínico não exibiu atividade antimicrobiana. As características de estabilidade físico-química tanto do shampoo matizante como do creme esfoliante foram avaliadas por ensaios de estabilidade acelerada aos $0,30,60$ e 90 dias de armazenamento a $40 \pm 2{ }^{\circ} \mathrm{C}$ e $75 \pm 5 \%$ de humidade relativa. Os produtos cosméticos preparados foram estáveis em relação às caracterisiticas físico-quimicas nas condições estudadas.
\end{abstract}

Palavras-chave: Jussara; Euterpe edulis Martius; antocianinas; shampoo matizante; creme exfoliante 


\section{Introduction}

The use of raw materials of plant origin in cosmetic products is a promising trend in the cosmetics industry, as consumers are increasingly looking for products that take advantage of the benefits that nature provides. The use of plant extracts in cosmetics has been highlighted by consumer demand, who are increasingly concerned with buying ecologically friendly products (1). In contrast to cosmetic ingredients of a synthetic nature, plant products are generally mild and biodegradable, exhibiting low toxicity (1-3). The aim of this research study was to evaluate the use of extracts from plant sources in different types of cosmetics, as a function of several interesting properties (3-5) such as antioxidant and antimicrobial activities, tyrosinase inhibition effect (1), and inhibition of the harmful effects of UVA radiation $(4,5)$, among other properties.

The fruit of the Jussara palm is considered an excellent source of anthocyanins, with anthocyanins being considered the most important group of water-soluble natural dyes, responsible for red, orange, pink, violet, blue, and purple colors in most flowers and fruits $(6,7)$. These bioactive molecules are water-soluble glycosides belonging to the flavonoid class and are derived from the flavylium cation or 2-phenylbenzopyrilium (8). Anthocyanins exhibit great potential for application in foods, pharmaceutical products and cosmetics, due to their wide range of colors, atoxicity, and beneficial effects on health (9). Anthocyanins are being studied for their high antioxidant capacity $(3,10)$, photoprotective efficacy (4), and coloring ability (11).

Cosmetics with the purpose of changing hair color, such as hair dye products, are used with high frequency. According to the durability of the color following hair dye application on hair strands, hair dying systems can be divided into temporary, semi-permanent, demipermanent and permanent (12). Natural pigments such as anthocyanins can be used in temporary stain applications, as in the process known as tinting. Temporary coloration is not effective in covering gray or white hair because the pigment only reaches the cuticle. These products sometimes are used to add shine and make the natural hair color more vibrant (13).

Another possible and interesting use of raw by-products from fruits involves the seeds, aiming at obtaining natural exfoliants. The seeds of the fruit of the Jussara palm can also be used for this purpose, since exfoliants of synthetic origin are proving to be potent environmental contaminants. Microplastics have accumulated in the oceans and marine sediments around the world in recent years, with maximum concentrations reach-

\section{Introdução}

A utilização de matérias-primas de origem vegetal em produtos cosméticos é uma tendência promissora na indústria de cosméticos, uma vez que os consumidores procuram cada vez mais produtos que tirem partido dos benefícios que a natureza proporciona. $\mathrm{O}$ uso de extratos vegetais em cosméticos tem se destacado pela demanda do consumidor, que se preocupa cada vez mais em comprar produtos ecologicamente corretos (1). Em contraste com os ingredientes cosméticos de natureza sintética, os produtos à base de plantas são geralmente mais suaves ebiodegradáveis, exibindo uma baixa toxicidade (1-3). O objetivo deste trabalho de investigação consistiu em avaliar a utilização de extractos de fontes vegetais em diferentes tipos de produtoscosméticos, em função de diversas propriedades interessantes (3-5) tais como atividades antioxidante e antimicrobiana, efeito inibidor da tirosinase (1), inibição dos efeitos prejudiciais dos raios UVA $(4,5)$, entre outras propriedades.

O fruto da palmeira Jussara é considerado uma excelente fonte de antocianinas, sendo estes pigmentos considerados o mais importante grupo de corantes naturais solúveis em água, responsáveis pelas cores vermelha, laranja, rosa, violeta, azul e roxa na maior parte das flores e frutos $(6,7)$. Estas moléculas bioativas são glicosídeos solúveis em água que pertencem à classe dos flavonóides e são derivados do catião flavilium ou 2-fenilbenzopirilium (8).

As antocininas exibem grande potencial de aplicação em alimentos, produtos farmacêuticos e cosméticos, devido à sua ampla gama de cores, atoxicidade e efeitos benéficos para a saúde (9). As antocianinas estão a ser estudadas devido à sua elevada capacidade antioxidade $(3,10)$, eficácia fotoprotetora (4) e capacidade colorante (11).

O uso de cosméticos com o objetivo de mudar a cor do cabelo, tais como produtos de coloração capilar, ocorre com elevada frequência. De acordo com a durabilidade da cor após aplicação de produtos de coloração capilar em mechas de cabelo, os sistemas de coloração podem ser divididos em temporário, semipermanente e permanente (12). Pigmentos naturais tais como as antocianinas podem ser utilizados em aplicações de coloração temporária, como no processo conhecido como matização. A coloração temporária não é tão eficaz em cobrir cabelos grisalhos ou brancos, porque o pigmento apenas alcança a cutícula. Por vezes, estes produtos são utilizados para conferir brilho e tornar a cor natural do cabelo num tom mais vibrante (13).

Outro possível e interessante uso de matérias-primas residuais provenientes de frutos envolve as sementes, 
ing 100000 particles per cubic meter. Because of their very small size, microplastics can be ingested by low trophic fauna, with consequences still unknown to the health of the organisms and the entire marine trophic chain (14). Microspheres obtained from synthetic polymers are used in hundreds of products, such as abrasives (including cosmetics intended for face and body wash), cleansers, moisturizers, and exfoliants, among others. Approximately $6 \%$ of liquid soaps and commercially available shower gels in Europe include plastic microspheres (15). The scientific evidence that points to the seriousness of environmental contamination by (micro) plastics have led some multinational companies to commit to eliminating these types of materials from their products by $2020(16,17)$.

In this sense, it is important to develop products or substances that are viable alternatives to synthetic exfoliants, for use as abrasives in cosmetics, with characteristics that are less aggressive to the environment, such as seed-based scrubs. Hence, the use of the Jussara fruit pulp residue as an exfoliating raw material for use in cosmetics can be quite interesting both from ecological and commercial points of view, leading to a complete valorization of this fruit and avoiding the generation of environmentally contaminating residues.

Due to the facts mentioned above, the present research work finds justification in the development of a tinting shampoo containing extract of anthocyanins and an exfoliating beauty cream incorporating granules derived from the seeds of the Jussara palm tree fruit (Euterpe edulis Martius).

\section{Material and Methods}

\section{Materials}

The fruits of Jussara palm tree (Euterpe edulis Martius) were a kind gift by Floricultura Campineira (Campinas, SP, Brazil), with its cultivation located in Jaguaruína (SP, Brazil). The fruits were stored under freezing conditions $\left(-18{ }^{\circ} \mathrm{C}\right)$ throughout the experiments. For the shampoo tint test, locks of blond human hair were purchased from the specialized company Lika Hair (Sorocaba, SP, Brazil). All the reagents used were of com o objetivo de obter esfoliantes naturais. As sementes do fruto da palmeira Jussara podem assim ser também utilizadas com este objetivo, uma vez que os esfoliantes de origem sintética têm-se revelado potentes contaminantes ambientais. Os microplásticos têm-se acumulado nos oceanos e nos sedimentos marinhos por todo o mundo nos últimos anos, com concentrações máximas a atingirem 100000 partículas por metro cúbico. Devido ao seu tamanho diminuto, os microplásticos podem ser ingeridos pela fauna trófica baixa, com consequências ainda desconhecidas para a saúde dos organismos e de toda a cadeia trófica marinha (14). As microesferas obtidas a partir de polímeros sintéticos são utilizadas em centenas de produtos, tais como abrasivos (incluindo cosméticos destinados à lavagem facial e lavagem corporal), produtos de limpeza, hidratantes, esfoliantes, entre outros. Cerca de $6 \%$ dos sabonetes líquidos e géis para banho disponíveis comercialmente na Europa têm adição de microesferas de plástico (15). A evidência científica que aponta para a gravidade da contaminação ambiental por (micro) plásticos tem levado algumas empresas multinacionais a comprometerem-se a eliminar estes tipos de materiais dos seus produtos até $2020(16,17)$.

Neste sentido, é importante o desenvolvimento de produtos ou substâncias que sejam alternativas viáveis aos esfoliantes sintéticos, para utilização como abrasivos em cosméticos, com características menos agressivas para o meio ambiente, tais como os esfoliantes oriúndos de sementes. Assim, a utilização do resíduo da polpa do fruto da Jussara como matéria-prima esfoliante para utilização em cosméticos pode ser bastante interessante, tanto do ponto de vista ecológico, como do ponto de vista comercial, levando à completa valorização deste fruto e evitando a geração de resíduos contaminantes do meio ambiente.

Devido aos fatos supramencionados, o presente trabalho de investigação encontra justificação no desenvolvimento de um shampoo matizante contendo extrato antocianínico e de um creme de beleza esfoliante incorporando grânulos derivados das semente do fruto da palmeira Jussara (Euterpe edulis Martius).

\section{Material e Métodos}

\section{Materiais}

Os frutos da palmeira Jussara (Euterpe edulis Martius) foram gentilmente cedidos pela Floricultura Campineira (Campinas, SP, Brasil), sendo proveniente da sua estação de cultivo localizada em Jaguaríuna (SP, Brasil). Os frutos foram armazenados sob condições de con- 
Table 1 - The composition of body exfoliation cream formulation

Tabela 1 Composição da formulação de creme esfoliante corporal

\begin{tabular}{|c|c|c|c|}
\hline INCI* Nomenclature / Nomenclatura INCI* & Function/ Função & $\begin{array}{c}\text { Commercial name / } \\
\text { Nome comercial }\end{array}$ & $\begin{array}{l}\%(\mathrm{w} / \mathrm{w}) \\
\%(\mathrm{~m} / \mathrm{m})\end{array}$ \\
\hline \multicolumn{4}{|c|}{ OILY PHASE / FASE OLEOSA } \\
\hline $\begin{array}{c}\text { Helianthus annuus (Sunflower) SEED OIL + XYLITOL } \\
\text { SESQUICAPRYLATE + GLYCERYL STEARATE + } \\
\text { Eurphobia cerifera (Candelilla) WAX + SODIUM HYDROXIDE }\end{array}$ & $\begin{array}{l}\text { Thickener and emulsifying agent / } \\
\text { Agente espessante e emulsificante }\end{array}$ & Emulfeel SGP / Emulfeel SGP & 5.00 \\
\hline PARAFFINUM LIQUIDUM & $\begin{array}{l}\text { Emollient fatty acid / } \\
\text { Ácido gordo emoliente }\end{array}$ & Mineral oil / Óleo mineral & 6.00 \\
\hline METHYLPARABEN & $\begin{array}{l}\text { Anti-fungal agent / } \\
\text { Agente antifúngico }\end{array}$ & $\begin{array}{c}\text { Methylparaben Nipagin }^{\circledR} / \\
\text { Metilparabeno Nipagin }^{\circledR}\end{array}$ & 0.18 \\
\hline PROPYLPARABEN & $\begin{array}{l}\text { Anti-fungal agent / } \\
\text { Agente antifúngico }\end{array}$ & $\begin{array}{l}\text { Propylparaben Nipazol }^{\circledR /} \\
\text { Propilparabeno Nipazol }\end{array}$ & 0.02 \\
\hline Euterpe edulis SEED POWDER & Exfoliant / Esfoliante & & 1.00 \\
\hline PROPYLENE GLYCOL & Humectant / Humectante & $\begin{array}{l}\text { Propylene glycol / } \\
\text { Propilenoglicol }\end{array}$ & 4.00 \\
\hline FRUIT EXTRACT & Fragrance / Perfume & Essence / Essência & 0.50 \\
\hline \multicolumn{4}{|c|}{ AQUEOUS PHASE / FASE AQUOSA } \\
\hline DISODIUM EDTA & $\begin{array}{l}\text { Chelating agent and viscosity controller/ } \\
\text { Agente quelante e controlador de viscosidade }\end{array}$ & EDTA & 0.10 \\
\hline WATER/ÁGUA & Solvent / Solvente & $\begin{array}{l}\text { Deionized water / } \\
\text { Água desionizada }\end{array}$ & $\begin{array}{l}\text { **q.s.p. } \\
100\end{array}$ \\
\hline
\end{tabular}

Table 2 - Formulation of shading shampoo for white, blond and discolored hair

Tabela 2 - Formulação de shampoo matizante para cabelos brancos, loiros e descolorados

\begin{tabular}{|c|c|c|c|}
\hline INCI* Nomenclature / Nomenclatura INCI* & Function/ Função & $\begin{array}{c}\text { Commercial name / } \\
\text { Nome comercial }\end{array}$ & $\begin{array}{l}\%(w / w) \\
\%(m / m)\end{array}$ \\
\hline \multicolumn{4}{|c|}{ PRESERVATIVE PHASE / FASE CONSERVANTE } \\
\hline PROPYLENE GLYCOL & Moisturizing / Humectante & $\begin{array}{c}\text { Propylene glycol / } \\
\text { Propilenoglicol }\end{array}$ & 5.00 \\
\hline METHYLPARABEN & $\begin{array}{l}\text { Anti-fungal agente / } \\
\text { Agente antifúngico }\end{array}$ & $\begin{array}{l}\text { Methylparaben / } \\
\text { Metilparabeno }\end{array}$ & 0.18 \\
\hline PROPYLPARABEN & $\begin{array}{l}\text { Anti-fungal agent / } \\
\text { Agente antifúngico }\end{array}$ & $\begin{array}{l}\text { Propylparaben / } \\
\text { Propilparabeno }\end{array}$ & 0.02 \\
\hline PROPYLPARABEN & $\begin{array}{l}\text { Anti-fungal agent / } \\
\text { Agente antifúngico }\end{array}$ & $\begin{array}{c}\text { Propylparaben } \\
\text { Nipazol }^{\circledR} / \\
\text { Propilparabeno } \\
\text { Nipazol }^{\circledR} \\
\end{array}$ & 0.02 \\
\hline \multicolumn{4}{|c|}{ WATER PHASE AND SURFACTANTS / FASE AQUOSA E TENSIOATIVOS } \\
\hline SODIUM LAURYL ETHER SULFATE & $\begin{array}{l}\text { Anionic Surfactant/ } \\
\text { Tensioativo aniónico }\end{array}$ & $\begin{array}{l}\text { Sodium lauryl ether } \\
\text { sulfate / Lauril éter } \\
\text { sulfato de sódio }\end{array}$ & 25.00 \\
\hline COCAMIDE DEA (SYNOTOL CN 90) & $\begin{array}{l}\text { Emulsifying agent / } \\
\text { Agente emulsificante }\end{array}$ & $\begin{array}{c}\text { Cocamide Dea } \\
\text { (Synotol CN 90)/ } \\
\text { Dietanolamida de ácido } \\
\text { gordo de coco } 90\end{array}$ & 3.50 \\
\hline WATER / ÁGUA & Solvent / Solvente & $\begin{array}{l}\text { Deionized water / } \\
\text { Água desionizada } \\
\end{array}$ & $\begin{array}{c}* * \text { q.s.p. } \\
100\end{array}$ \\
\hline \multicolumn{4}{|c|}{ EXTRACT AND FRAGRANCE / EXTRATO E ESSÊNCIA } \\
\hline FRUIT EXTRACT & Fragrance / Perfume & Essence / Essência & 0.50 \\
\hline Euterpe edulis FRUITS EXTRACT & $\begin{array}{c}\text { Antioxidant and color donor/ } \\
\text { Antioxidante e colorante }\end{array}$ & Colorant / Colorante & $0.3 \%$ \\
\hline \multicolumn{4}{|c|}{ pH ADJUSTMENT / CORREÇÃO DO pH } \\
\hline TRIETHANOLAMINE & Basifying / Basificante & $\begin{array}{c}\text { Triethanolamine } 20 \% / \\
\text { Trietanolamina } 20 \% \\
\end{array}$ & $\begin{array}{c}\text { q.s.p. } \mathrm{pH} \\
6 \\
\end{array}$ \\
\hline CITRIC ACID & Acidulant / Acidificante & $\begin{array}{l}\text { Citric Acid / } \\
\text { Ácido cítrico } \\
\end{array}$ & $\begin{array}{c}\text { q.s.p. } \mathrm{pH} \\
6 \\
\end{array}$ \\
\hline \multicolumn{4}{|c|}{ GELIFYING AGENT / GELIFICANTE } \\
\hline HYDROXYETHYLCELLULOSE & Thickener / Espessante & $\begin{array}{c}\text { Hydroxyethylcellulose } \\
\left(\text { Natrosol }^{\circledR}\right) / \\
\text { Hidroxietilcelulose } \\
\left(\text { Natrosol }^{\mathbb{}}\right)\end{array}$ & 1.00 \\
\hline
\end{tabular}

* International Nomenclature of Cosmetic Ingredients / * Nomenclatura Internacional de Ingredientes Cosméticos; $* *$ q.s.p. $=$ quantity sufficient per $/ * *$ q.s.p. $=$ quantidade suficiente para 
pro-analysis (PA) grade and the water used was purified in a Milli- ${ }^{\circledR}$ system until a final conductivity of 18.2 $\mathrm{M} \Omega . \mathrm{cm}^{-1}$. All components used in the preparation of cosmetics were of pharmaceutical grade and were either purchased from specialized distributors or kindly donated by Chemyunion Química Ltda (Sorocaba, SP, Brazil). The formulations used in the preparation of the cosmetics are detailed in Tables 1 and 2.

\section{Methods}

The first part of the experimental work was focused on obtaining and characterizing the anthocyanin extract produced from the fruits of the Jussara palm tree. After the extraction process, the exfoliating granules were prepared from the anthocyanin extraction residues (fruit seeds) and duly characterized. The second part of the experimental work was focused on developing and characterizing the cosmetic formulations (tinting shampoo and exfoliating cream) and the determination of their physical-chemical stability.

\section{Preparation of anthocyanin extracts}

The anthocyanin extraction process was performed according to the procedure described by Favaro et al. (18). The anthocyanin extraction was made by combining the Jussara fruit pulp with $94 \%$ ethanol (solvent) in a 1:3 ratio (fruit:solvent, w/v). The first step of the process consisted of manually removing the pulp from the Jussara fruit with a knife. The pulp obtained was weighed and the solvent added. The solution was placed in a thermostated bath set at $55^{\circ} \mathrm{C}$ (Novatécnica, model NT 230, Piracicaba, SP, Brazil) for the extraction of anthocyanins. After $30 \mathrm{~min}$, the macerate was filtered on qualitative filter paper to obtain the liquid extract. The extract was then dried in a fume hood with air circulation for approximately $6 \mathrm{~h}$, in the absence of light. The dried extract was then stored in a polyethylene flask wrapped with aluminium foil for protection from light, under freezing conditions $\left(-18^{\circ} \mathrm{C}\right)$.

\section{Quantification of anthocyanins in the extract}

The spectrophotometric differential $\mathrm{pH}$ method was used to quantify the anthocyanins present in the dry extract (19). Absorbance readings of the samples were performed at the wavelengths of $520 \mathrm{~nm}$ and $700 \mathrm{~nm}$ in a UV-Vis spectrophotometer (Multispec, model 1501, Shimadzu, Tokyo, Japan). The anthocyanin content gelação $\left(-18{ }^{\circ} \mathrm{C}\right)$ durante todo o procedimento experimental. Para o teste de matização do shampoo foram utilizadas mechas de cabelos loiros de origem humana adquiridas à empresa especializada Lika Hair (Sorocaba, SP, Brasil). Todos os reagentes utilizados foram de grau pró-análise (PA) e a água utilizada foi purificada num sistema Milli- ${ }^{\circledR}$ até uma condutividade final de $18.2 \mathrm{M} \Omega . \mathrm{cm}^{-1}$. Todos os componentes utilizados na preparação dos cosméticos foram de grau farmacêutico, tendo sido ou adquiridos em distribuidoras especializadas ou gentilmente cedidos pela empresa Chemyunion Química Ltda (Sorocaba,SP, Brasil). As formulações utilizadas na preparação dos cosméticos podem ser encontradas nas Tabelas 1 e 2 .

\section{Métodos}

A primeira parte do trabalho experimental focou-se na obtenção e caracterização de um extrato de antocianinas produzido a partir dos frutos da palmeira Jussara. Após o processo de extração, os grânulos esfoliantes foram preparados a partir dos resíduos da extração das antocianinas (sementes dos frutos) e devidamente caracterizados. A segunda parte do trabalho experimental focou-se no desenvolvimento e determinação da estabilidade físico-química de formulações cosméticas (shampoo matizante e creme de beleza esfoliante).

\section{Preparação dos extratos antocianínicos}

O processo de extração das antocianinas foi realizado de acordo com o procedimento descrito por Favaro et al. (18). A extração das antocianinas foi feita adicionando a polpa dos frutos da Jussara com solvente na proporção 1:3 (fruta:solvente, $\mathrm{m} / \mathrm{v}$ ), utilizando-se como solvente uma solução de etanol 94\% . A primeira etapa do processo consistiu na remoção manual da polpa do fruto da Jussara com auxílio de uma faca. A polpa assim obtida foi pesada e adicionado o solvente. Esta solução foi colocada em banho termostatizado a $55^{\circ} \mathrm{C}$ (Novatécnica, modelo NT 230, Piracicaba, SP, Brasil) para extração das antocianinas. Após $30 \mathrm{~min}$, o macerado foi filtrado em papel de filtro qualitativo por forma a obter o extrato húmido. Este extrato húmido foi então seco numa hotte com circulação de ar durante aproximadamente $6 \mathrm{~h}$, na ausência de luz. O extrato seco foi depois armazenadonum frasco de polietileno envolvido por folha de alumínio para proteção contra a luz, sob condições de congelação $\left(-18^{\circ} \mathrm{C}\right)$.

\section{Quantificação das antocianinas no extrato}

O método utilizado para quantificar as antocianinas presentes no extrato seco foi o método espectrofotométrico do pH diferencial (19). As leituras de absorvância das 
was calculated as cyanidin-3-glycoside ( $\mathrm{MW}=449.2$ $\mathrm{g} / \mathrm{mol}$ ) equivalent, using Equation 1.

$$
C\left(\frac{m g \text { anthocyanin }}{100 \text { g fruit }}\right)=\frac{\left(\left(A_{510 n m}-A_{700 n m}\right)_{p H 1.0}-\left(A_{510 n m}-A_{700 n m}\right)_{p H} 4.5\right) \cdot M W \cdot D F}{\varepsilon \cdot 1}
$$

where $A$ is absorbance, $\varepsilon$ is the molar absorptivity (26900 mol.dm ${ }^{1 \mathrm{vg}}$ ), DF is the dilution factor, MW is the molecular weight of cyanidin-3-glycoside, and 1 is the thickness of the cuvette $(\mathrm{cm})$.

\section{Antioxidant activity of the extract}

The antioxidant activity was determined by the phospho-molybdenum complex method, which is based on the reduction of molybdenum (VI) to molybdenum (V) in the presence of a substance with antioxidant capacity (20). The percentage of antioxidant activity (\% AA) was calculated using Equation 2.

$$
\% A A=\frac{A_{\text {sample }}-A_{\text {blank }}}{A_{\text {ascorbic acid }}-A_{\text {blank }}} \times 100
$$

where $A_{\text {sample }}$ is the absorbance of the sample, $A_{\text {blank }}$ is the absorbance of the blank, and $\mathrm{A}_{\text {ascorbic acid }}$ is the absorbance of ascorbic acid.

\section{Antimicrobial activity of the extract}

The antimicrobial activity of the Jussara extract was determined by the antimicrobial susceptibility test using the disc-diffusion technique (21). The bacterial strains used were Staphylococcus aureus (CCCD-S007), Pseudomonas aeruginosa (CCCD-P004) and Escherichia coli (CCCD-E003) (Cefar Diagnostica Culture Collection, São Paulo, Brazil). The culture medium was TSA (Trypticase Soy Agar) from Fluka (St. Louis MO, USA). Ultrapure water was used as a negative control, and penicillin/streptomycin (Vitrocell, Campinas, SP, Brazil) was used as a positive control.

Preparation of the exfoliating agent from the seeds of the Jussara fruit

The seeds were separated, washed with ultrapure water and dried in an incubating chamber (Fanem, model 515, Guarulhos, Brazil) at $100{ }^{\circ} \mathrm{C}$ for $24 \mathrm{~h}$. The dried residue was then milled in a Willey knife mill (Marconi, model MA340, Piracicaba, Brazil) and the powder obtained was graded to determine the size of the granules produced. amostras foram realizadas aos comprimentos de onda de $520 \mathrm{~nm}$ e $700 \mathrm{~nm}$ num espectrofotômetro UV-Vis (Multispec, modelo 1501, Shimadzu, Tóquio, Japão). O teor em antocianinas foi calculado como equivalente da cianidina-3-glicosídeo ( $\mathrm{MM}=449,2 \mathrm{~g} / \mathrm{mol})$, utilizandose a Equação 1.

$$
C\left(\frac{m g \text { anthocyanin }}{100 \text { g fruit }}\right)=\frac{\left(\left(A_{510 n m}-A_{700 n m}\right)_{p H} 1.0-\left(A_{510 n m}-A_{700 n m}\right)_{p H 4.5}\right) \cdot M W \cdot D F}{\varepsilon \cdot 1} \quad \text { (Eq. 1) }
$$

onde A é a absorvância, $\varepsilon$ é a absortividade molar (26900 mol.dm ${ }^{-3}$ ), DF é o fator de diluição, MM é a massa molecular da cianidina-3-glicosídeo; e 1 é a espessura da cuvete $(\mathrm{cm})$.

\section{Atividade antioxidante do extrato}

A atividade antioxidante foi determinada pelo método do complexo fosfomolibdénio, o qual é baseado na redução do molibdénio (VI) a molibdénio (V) na presença de uma substância com capacidade antioxidante (20). A percentagem de atividade antioxidante (\% AA) foi calculada utilizando a Equação 2.

$$
\% A A=\frac{A_{\text {amostra }}-A_{\text {branco }}}{A_{\text {ácido ascórbico }}-A_{\text {branco }}} \times 100
$$

onde $\mathrm{A}_{\text {amostra }}$ é a absorvância da amostra, $\mathrm{A}_{\text {branco }}$ é a absorvância do branco, e $\mathrm{A}_{\text {ácido ascórbico }}$ é a absorvância do ácido ascórbico.

\section{Atividade antimicrobiana do extrato}

A atividade antimicrobiana do extrato de Jussara foi determinada pelo teste de sensibilidade a antimicrobianos, utilizando a técnica de disco-difusão (21). As estirpes bacterianas utilizadas foram Staphylococcus aureus (CCCD-S007), Pseudomonas aeruginosa (CCCD-P004) e Escherichia coli (CCCD-E003) (Coleção de Culturas Cefar Diagnóstica, São Paulo, Brasil). O meio de cultura utilizado foi o TSA (Trypticase Soy Agar) da marca Fluka (St. Louis, MO, EUA). Como controle negativo utilizou-se água ultrapura e como controle positivo utilizou-se penicilina/estreptomicina (Vitrocell, Campinas, SP, Brasil).

Preparação do agente esfoliante a partir das sementes do fruto da Jussara

As sementes foram separadas, lavadas com água ultrapura e secas em estufa (Fanem, modelo 515, Guarulhos, Brasil) a $100{ }^{\circ} \mathrm{C}$ durante 24 h. O resíduo seco foi então triturado em moinho de facas do tipo Willey (Marconi, modelo MA340, Piracicaba, Brasil) e o pó obtido foi tamizado visando determinar o tamanho dos grânulos produzidos. 
Determination of the granulometry of the exfoliating agent

The granulometry of the exfoliating agent was determined by sieving, using an electromagnetic sieve agitator for granulometric analysis (Bertel, Caieiras, Brazil). Approximately $100 \mathrm{~g}$ of sample were poured in the highest granulation sieve and the sieve stack was shaken at 60 vibrations per second for $15 \mathrm{~min}$. The amount of powder remaining in each sieve was determined, and Equation 3 was used to calculate the mean particle size $(\mathrm{mm})(22)$.

$$
d=\frac{\sum(\% \text { retained }) x(\text { average aperture })}{100}
$$

where $\mathrm{d}$ is the average diameter $(\mathrm{mm}), \%$ retained is the percentage fraction retained on each sieve, and average aperture is the average aperture of the mesh $(\mathrm{mm})$ in each granulometric class.

\section{Density of granules}

The density of the granules was determined by pycnometry, using a helium pycnometer from Quantachromed Instruments (model Ultrapyc 1200e, Boynton Beach, FL, USA).

\section{Scanning electron microscopy}

The surface microstructure of the granules was observed in a Scanning Electron Microscope (SEM) from JEOL (model JSM-63660, Tokyo, Japan).

\section{Preparation of cosmetic products}

Preparation of cosmetics (shading shampoo and body exfoliating cream) followed the Good Manufacturing and Control Practices established by Resolution of Directors Collective (RDC) 67/2017 of Anvisa (Brazilian National Health Surveillance Agency) (23).

The shampoo was prepared in a $100 \mathrm{~mL}$ beaker by dissolving propylene glycol, methyl paraben, and propyl parabenin deionized water, followed by heating to 70 ${ }^{\circ} \mathrm{C}$. This was called the preservative phase. Afterward, in another $100 \mathrm{~mL}$ beaker, lauryl sulfate and coconut fatty acid diethylamide were homogenized with cold deionized water at $300 \mathrm{rpm}$. This was the surfactant phase. The two phases (preservative and surfactant) were then mixed in another beaker and duly homogenized using a magnetic stirrer at $300 \mathrm{rpm}$. The $\mathrm{pH}$ was corrected to 6.0 via the dropwise addition of citric acid or triethanolamine. A $30 \%(\mathrm{w} / \mathrm{w}) \mathrm{NaCl}$ solution was then dripped into the solution until the desired viscosity was reached, evaluated by the physical appearance of the shampoo. Afterward, natrosol was sprayed onto
Determinação da granulometria do agente esfoliante

A granulometria do agente esfoliante foi determinada pelo método da tamização, utilizando um agitador electromagnético de peneiras para análises granulométricas (Bertel, Caieiras, Brasil). Cerca de 100 g de amostra foram colocadas no tamis de maior granulação e em seguida a pilha de tamizes foi agitada a 60 vibrações por segundo durante $15 \mathrm{~min}$. Determinou-se a quantidade de pó restante em cada tamis e, para o cálculo do tamanho médio das partículas (mm), utilizou-se a Equação 3 (22).

$$
d=\frac{\sum(\% \text { retida }) x(\text { abertura média })}{100}
$$

onde d é o diâmetro médio ( $\mathrm{mm}), \%$ retida é a percentagem da fração retida em cada tamis, e abertura média é a abertura média da malha $(\mathrm{mm})$ em cada classe granulométrica.

\section{Densidade dos grânulos}

A densidade dos grânulos foi determinada por picnometria, utilizando-se um picnómetro de hélio da marca Quantachrome Instruments (modelo Ultrapyc 1200e, Boynton Beach, FL, EUA).

\section{Microscopia eletrónica de varrimento}

A microestrutura de superfície dos grânulos foi observada num Microscópio Eletrónico de Varrimento (MEV) da marca JEOL (modelo JSM-63660, Tóquio, Japão).

\section{Preparação dos produtos cosméticos}

A preparação dos produtos cosméticos (shampoo matizante e creme esfoliante corporal) seguiu as Boas Práticas de Fabricação e Controle estabelecidas pela Resolução da Diretoria Colegiada (RDC) 67/2007 da Anvisa (Agência Nacional de Vigilância Sanitária do Brasil) (23).

O shampoo foi preparado num gobelé de $100 \mathrm{~mL}$, através da adição de propilenoglicol, metilparabeno e propilparabeno, e dissolução em água deionizada, seguido de aquecimento a $70{ }^{\circ} \mathrm{C}$. Esta fase foi denominada fase conservante. De seguida, num outro gobelé de $100 \mathrm{~mL}$, os tensioativos lauril sulfato de sódio e dietilamida de ácidos gordos de coco foram dissolvidos a frio em água desionizada com homogeneização magnética a 300 rpm. Esta fase foi denominada de fase surfactante. As duas fases (conservante e surfactante) foram misturadas num outro gobelé e devidamente homogeneizadas por agitação magnética a $300 \mathrm{rpm}$. $\mathrm{O}$ pH foi corrigido para 6,0 por adição de gotas de acido cítrico ou trietanolamina. Em seguida, uma solução de $\mathrm{NaCl}$ a $30 \%(\mathrm{~m} / \mathrm{m})$ foi 
the shampoo, which was gently homogenized by hand to prevent foaming. Finally, the Jussara extract was added in a $0.3 \%(\mathrm{w} / \mathrm{w})$ ratio and the formulation was homogenized by gentle stirring (24). Tests with $0.2,0.3$ and $0.4 \%(\mathrm{w} / \mathrm{v})$ anthocyanin extract were performed in order to determine the best shading effect for the shampoo. Colour fixation analysis was performed using locks of blond human hair. The locks were manually cleaned with neutral shampoo $(5 \mathrm{~mL})$ and immediately washed with shading shampoos $(5 \mathrm{~mL})$ containing different anthocyanin concentrations.

The exfoliating beauty cream was initially prepared by separately heating all components of the oil phase to the melting point of solid fatty substances $\left(\mathrm{ca} .70{ }^{\circ} \mathrm{C}\right.$ ). The aqueous phase components were heated to $75^{\circ} \mathrm{C}$ and then slowly added to the oil phase with manual stirring until cooled to room temperature $\left(25^{\circ} \mathrm{C}\right)$. Subsequently, the seed granules (previously hydrated) were added at a ratio of $1 \%(\mathrm{w} / \mathrm{v})$ of the total volume of the formulation. The samples were stored in polyethylene containers at room temperature $\left(25^{\circ} \mathrm{C}\right)$ under light protection until the execution of the preliminary stability and accelerated stability tests.

\section{Physical-chemical stability tests}

Preliminary stability tests (freeze-thaw cycle, centrifugation test, and thermal stress) were performed $24 \mathrm{~h}$ after the preparation of the cosmetic products. Following, the samples were stored either at room temperature $(25$ $\left.\pm 2{ }^{\circ} \mathrm{C}\right)$ or in an incubating chamber $\left(40 \pm 2{ }^{\circ} \mathrm{C}\right.$ and 75 $\pm 5 \%$ relative humidity $(\mathrm{RH}))$ and subjected to the accelerated stability test at $0,30,60$ and 90 days of storage. For the body exfoliating cream, the organoleptic characteristics, $\mathrm{pH}$, viscosity and scatter ability tests were also performed, while for the shading shampoo the organoleptic characteristics, $\mathrm{pH}$ and relative density tests were performed (25). gotejada até se atingir a viscosidade desejada determinada pela aparência física do shampoo. Na sequência, pulverizou-se natrosol sobre o shampoo que foi então suavemente homogeneizado manualmente por forma a evitar a formação de espuma. Finalmente, o extrato de Jussara foi adicionado na proporção de $0,3 \%(\mathrm{~m} / \mathrm{m})$ e a formulação foi homogeneizada por agitação suave (24). Foram realizados ensaios com concentrações mássicas de extrato antocianínico de 0,2, 0,3 e 0,4\% $(\mathrm{m} / \mathrm{v})$, de modo a determinar o melhor efeito matizante para o shampoo. A análise da fixação de cor foi realizada utilizando-se mechas de cabelos loiros de origem humana. As mechas foram manualmente higienizadas com shampoo neutro $(5 \mathrm{~mL})$ e imediatamente lavadas com os shampoos matizantes $(5 \mathrm{~mL})$ contendo diferentes concentrações de antocianina.

$\mathrm{O}$ creme esfoliante foi inicialmente preparado aquecendo-se, separadamente, todos os componentes da fase oleosa até ao ponto de fusão das substâncias gordas sólidas (cerca de $70^{\circ} \mathrm{C}$ ). Os componentes da fase aquosa foram aquecidos a $75^{\circ} \mathrm{C}$ e depois lentamente adicionados à fase oleosa sob agitação manual, até arrefecimento à temperatura ambiente $\left(25^{\circ} \mathrm{C}\right)$. Subsequentemente, os grânulos das sementes (previamente hidratados) foram adicionados na proporção de $1 \%(\mathrm{~m} / \mathrm{v})$ em relação ao volume total da formulação. As amostras foram armazenadas em recipientes de polietileno, mantidas em temperatura ambiente $\left(25^{\circ} \mathrm{C}\right.$ ) sob proteção da luz até a realização dosdos testes de estabilidade preliminar e acelerada.

\section{Ensaios de estabilidade físico-química}

Após a preparação dos produtos cosméticos (24 h), realizaram-se os ensaios de estabilidade preliminar (ciclo de congelação-descongelação, teste de centrifugação e stress térmico). Na sequência, as amostras foram armazenadas tanto à temperatura ambiente $\left(25 \pm 2{ }^{\circ} \mathrm{C}\right)$ como em estufa $\left(40 \pm 2{ }^{\circ} \mathrm{C}\right.$ e $75 \pm 5 \%$ de umidade relativa (UR)), e sujeitas ao teste de estabilidade acelerada após 0, 30, 60 e 90 dias de armazenamento. Para o creme esfoliante corporal, realizaram-se também os ensaios de características organolépticas, $\mathrm{pH}$, viscosidade e espalhabilidade, enquanto que para o shampoo matizante foram realizados os ensaios de características organolépticas, $\mathrm{pH}$ e densidade relativa (25). 


\section{Results and Discussion}

\section{Characterization of dry anthocyanin extract}

The most commonly used solvents for anthocyanin extraction from fruits are aqueous mixtures of ethanol, methanol, or acetone. Extraction with methanol is the most efficient, but ethanol is preferred due to its much lower toxicity (9). The use of hydroalcoholic solutions varies from $50 \%$ to $95 \%(\mathrm{v} / \mathrm{v})$ in several extraction processes. $(7,24,26)$ The yield of the extraction process was $2.3 \%(\mathrm{w} / \mathrm{w})(2.25 \mathrm{~g}$ dry extract/100 g fruit) and could be considered efficient. The total concentration of anthocyanins in the extract was $1.09 \pm 0.10 \mathrm{~g} / 100$ g pulp, so Jussara fruits proved to be a good source of this pigment. However, the evaluation of these parameters should also consider the degree of maturation of the fruit and the geographic location of the plant source, among other factors $(25,27)$.

The antioxidant activity of the anthocyanin extract obtained from the fruit of Jussara was $139.0 \pm 5.5 \%$ in relation to the ascorbic acid, indicating a high antioxidant capacity of the extract. This property has been observed in other reported works (28-30). However, in the present study, no antimicrobial activity whatsoever was observed in the extract against the microorganisms studied.

\section{Characterization of granules}

After cleaning, drying, and grinding the seeds, the granulometry was determined, with granules of an average diameter of $650 \mu \mathrm{m}$ obtained. By evaluating different commercial exfoliating products, it was observed that the sizes of the plastic microspheres employed varied from $60 \mu \mathrm{m}$ to $800 \mu \mathrm{m}$ in diameter (31). Thus, the particle size of the granules produced proved to be suitable for use in cosmetics.

In addition, the density of the granules in the helium pycnometer was determined in order to verify the buoyancy capacity of the cosmetic products. The results obtained were $1.3559 \pm 0.0018 \mathrm{~g} \mathrm{~cm}^{-3}(\mathrm{n}=5)$. This value indicated that the granules would not be able to remain suspended in liquid samples. Therefore, we chose to aggregate the granules in an exfoliating cream due to its higher viscosity.

There was also a concern in assessing the micromorphology of the particles obtained, because irregular edges can irritate the skin. causing micro-scratches, lesions, and inflammation (32). The scanning electron microscopy photomicrographies (Figure 1) revealed that the particles produced by the grinding process are irregular. Therefore, they were not suitable for incor-

\section{Resultados e Discussão}

\section{Caracterização do extrato antocianínico seco}

Os solventes mais utilizados para a extração de antocianinas a partir de frutos são misturas aquosas de etanol, metanol ou acetona. A extração com metanol é a mais eficiente, mas o etanol é preferido devido à sua muito menor toxicidade (9). O uso de soluções hidroalcoólicas varia entre $50 \%$ a $95 \%(\mathrm{v} / \mathrm{v})$ em vários processos de extração $(7,25,26)$. O rendimento do processo de extração foi de $2,3 \%(\mathrm{~m} / \mathrm{m})(2,25 \mathrm{~g}$ extrato seco/100 g fruto) e pode ser considerado eficiente. A concentração total de antocianinas no extrato foi de 1,09 $\pm 0,10 \mathrm{~g} /$ $100 \mathrm{~g}$ polpa, pelo que os frutos da palmeira Jussara provaram ser uma boa fonte deste pigmento. No entanto, a avaliação destes parâmetros deve também considerar o grau de maturação do fruto, a localização geográfica da planta, entre outros fatores $(25,27)$.

A atividade antioxidante do extrato antocianínico obtido a partir do fruto da Jussara foi de 139,0 $\pm 5,5 \%$ em relação ao ácido ascórbico, indicando assim uma elevada capacidade antioxidante do extrato. Esta propriedade foi também observada em outros trabalhos encontrados na literatura (28-30). No entanto, neste trabalho de investigação não foi observada qualquer atividade antimicrobiana do extrato contra os microrganismos estudados.

\section{Caracterização dos grânulos}

Após limpeza, secagem e trituração das sementes, determinou-se a granulometria, tendo-se obtido grânulos com um diâmetro médio de $650 \mu \mathrm{m}$. Através da avaliação de diferentes produtos esfoliantes comercializados no mercado, observou-se que os tamanhos das microesferas de plástico utilizadas variavam entre $60 \mu \mathrm{m}$ e $800 \mu \mathrm{m}$ de diâmetro (31). Desta forma, o tamanho dos grânulos produzidos neste estudo mostrou-se adequado para o uso em cosméticos.

Adicionalmente, determinou-se a densidade dos grânulos em picnómetro de hélio, com o objetivo de verificar a capacidade de flutuabilidade em produtos cosméticos. Os resultados obtidos foram de 1,3559 $\pm 0,0018 \mathrm{~g} \mathrm{~cm}^{-3}$ $(\mathrm{n}=5)$. Este valor indicou que os grânulos não seriam capazes de se manterem em suspensão em amostras líquidas. Assim, optou-se por agregar os grânulos num creme esfoliante em função da sua maior viscosidade. Existiu também a preocupação em avaliar a micromorfologia das partículas obtidas, pois rebordos irregulares podem irritar a pele causando micro-arranhões, lesões e inflamação (32). Por observação das imagens de microscopia eletrónica de varrimento (Figura 1), observou-se 


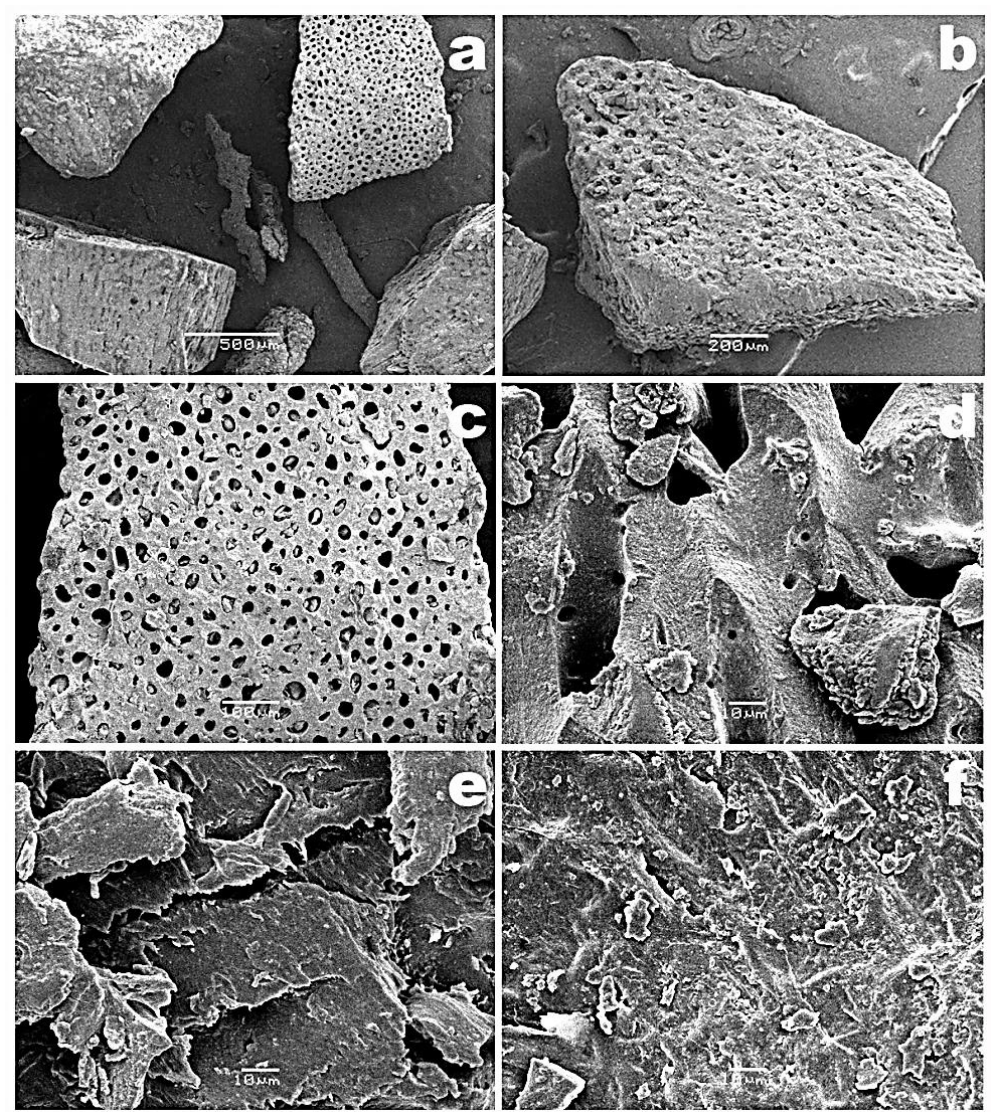

Figure 1 - Scanning Electron Microscopy Photomicrographs of Jussara fruit seed granules, obtained after the grinding process by knife milling, at various magnifications ( $\mathrm{a}, \mathrm{x} 50$; $\mathrm{b}, \mathrm{x} 75 ; \mathrm{c}, \mathrm{x} 150$; d, x1000; e, x1000; f, x1000)

Figura 1 -Fotomicrografias de microscopia eletrónica de varrimento de grânulos de semente de fruto de Jussara, obtidas após o processo de trituração por moinho de facas, para várias magnificações (a, x50; b, x75; c, x150; d, x1000; e, x1000; f, x1000)

poration into cosmetic preparations intended for facial exfoliation. Thus, we chose to incorporate the particles produced in a cream for body exfoliation.

\section{Characterization of shading shampoos}

When the shampoo containing $0.2 \%(\mathrm{w} / \mathrm{v})$ of anthocyanin extract was used, there was almost no change in color in the hair strand. With the use of the shampoo containing $0.4 \%(\mathrm{w} / \mathrm{v})$ anthocyanin extract, the blonde tone of hair was darkened more than expected. Thus, the concentration of $0.3 \%(\mathrm{w} / \mathrm{v})$ anthocyanin extract was set as the most suitable for the production of the shading shampoo. Figure 2 shows the locks of hair tinted with the three prepared shampoos.

The anthocyanin extract exhibited good ability as a colorant. However, this ability has still been little explored for cosmetic uses. Studies point to the use of anthocyanins as a dye in lipsticks (33) and hair coloring sprays que as partículas produzidas pelo processo de trituração são irregulares. Assim, não são indicadas para incorporação em preparações cosméticas intencionadas para esfoliação da face. Optou-se, portanto, pela incorporação das partículas produzidas num creme para esfoliação corporal.

\section{Caracterização do shampoo matizante}

Quando foi utilizado o shampoo contendo 0,2\% (m/v) de extrato antocianínico quase não houve alteração de cor na mecha de cabelo. Já com a utilização do shampoo contendo $0,4 \%(\mathrm{~m} / \mathrm{v})$ de extrato antocianínico, o tom de loiro da mecha de cabelo escureceu mais do que o previsto. Assim, determinou-se como mais adequada para a produção do shampoo matizante a concentração de $0,3 \%(\mathrm{~m} / \mathrm{v})$ de extrato antocianínico de Jussara. A Figura 2 apresenta as mechas de cabelo matizadas com os shampoos.

O extrato de antocianinas demonstrou boa capacidade como colorante. Contudo, esta capacidade ainda tem 


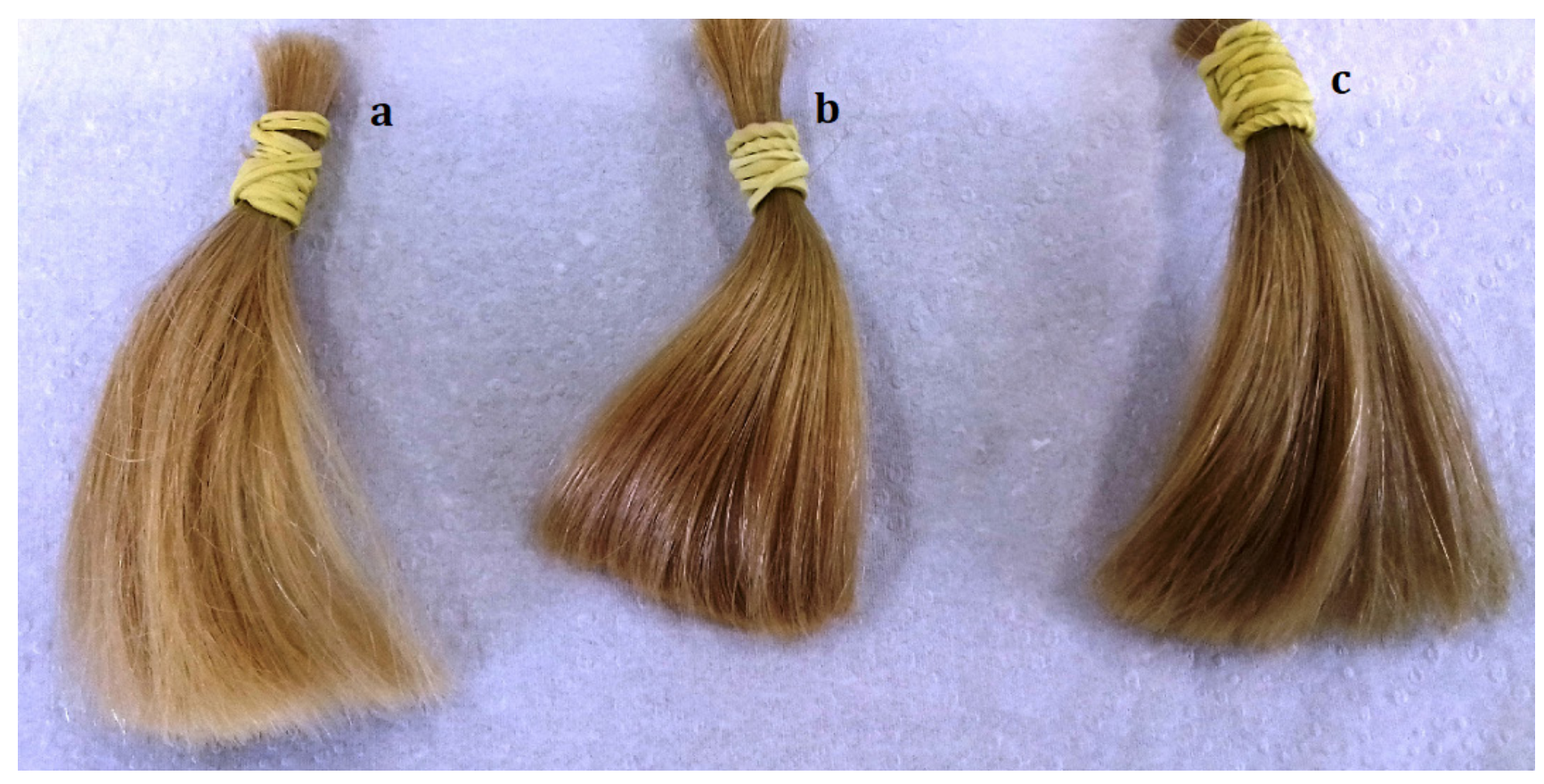

Figure 2 - Photographs of locks of hair after washing with shading shampoos with different concentrations of Jussara extract $(a=0.2 \%, b=0.3 \%$ and $c=0.4 \% \mathrm{w} / \mathrm{v})$

Figura 2 - Fotografias de mechas de cabelo após a lavagem com os shampoos matizantes com diferentes concentrações de extrato de Jussara ( $a=0,2 \%, b=0,3 \%$ e $c=0,4 \% \mathrm{~m} / \mathrm{v}$ )

(34). However, it has been observed that the hair fiber has a high anthocyanin accumulation capacity and excellent washing stability (35).

The methods used to assess the quality of the shading shampoo involved sensorial and physicochemical analyses (36), evaluating organoleptic characteristics, $\mathrm{pH}$ value, height and stability of the foam formed, relative density and apparent viscosity. Table 3 displays the results obtained in these procedures.

Regarding the $\mathrm{pH}$ value, it is recommended that shampoos for daily use have a $\mathrm{pH}$ value ranging from 5 to 7. Hence, the shading shampoo produced, with a $\mathrm{pH}$ value between 5.5 and 6 , was considered adequate as a product for capillary use. The relative density of the shading shampoo was $1.064 \mathrm{~g} \mathrm{~cm}^{-3}$, an expected value and within the standards of a shampoo-type product. Apparent viscosity and density are important rheological properties for the acceptance of a cosmetic product, as they are related to the quality of the product. Although the foam formed is not directly linked to the cleaning process, it represents an important sensory factor for the consumer $(33,37)$. Adequate foaming was observed in the formulated shampoo, which can be considered as a positive quality factor for the product. sido pouco explorada no uso em cosméticos. Trabalhos de investigação apontam o uso de antocianinas como corantes em batons (33) e sprays para coloração de cabelos (34). No entanto, tem sido observado que a fibra capilar possui elevada capacidade de acumulação de antocianinas com excelente estabilidade à lavagem (35).

Os métodos utilizados para avaliação da qualidade do shampoo matizante envolveram análises sensoriais e físico-químicas (36), sendo avaliadas características organolépticas, $\mathrm{pH}$, altura e estabilidade da espuma formada, densidade relativa e viscosidade aparente. A Tabela 3 apresenta os resultados obtidos nestes ensaios.

Em relação ao valor do $\mathrm{pH}$, é recomendado que os shampoos de utilização diária apresentem valores de $\mathrm{pH}$ entre 5 e 7 . Assim, o shampoo matizante produzido, com valor de $\mathrm{pH}$ entre 5,5 e 6,0 , foi considerado adequado como produto de uso capilar. A densidade relativa do shampoo matizante foi de $1,064 \mathrm{~g} \mathrm{~cm}^{-3}$, um valor esperado e dentro dos padrões de um produto do tipo shampoo. A viscosidade aparente e a densidade são propriedades reológicas importantes para a aceitação de um produto cosmético, pois estão relacionadas com a qualidade do produto. Ainda que a espuma formada não esteja diretamente ligada ao processo de limpeza, 
Table 3 - Results obtained for the quality parameters of shading shampoo produced with $0.3 \%(\mathrm{w} / \mathrm{v})$ of anthocyanin extract obtained from the fruits of Jussara palm tree

Tabela 3 - Resultados obtidos para os parâmetros de qualidade do shampoo matizante produzido com $0,3 \%(\mathrm{~m} / \mathrm{v})$ de extrato antocianínico obtido a partir do fruto da palmeira Jussara

\begin{tabular}{|c|c|}
\hline Parameter evaluated / Parâmetro avaliado & Results obtained / Resultados obtidos \\
\hline $\mathrm{pH}$ & $6.070 \pm 0.085$ \\
\hline Viscosity* / Viscosidade* $^{*}$ & $10.6439 \pm 0.816 \mathrm{cSt}$ \\
\hline Relative density** / Densidade relativa** & $1.064 \pm 0.085 \mathrm{~g} \mathrm{~cm}^{-3}$ \\
\hline Foam formation and stability / \\
Formação e estabilidade da espuma & $\begin{array}{c}14 \mathrm{~cm} \text { of height } / / 10 \mathrm{~min} . / \\
14 \mathrm{~cm} \text { de altura / } 10 \mathrm{~min} .\end{array}$ \\
\hline Colour / Cor & $\begin{array}{c}\text { Reddish (Absorbance }=1.548 \mathrm{a} 550 \mathrm{~nm}) / \\
\text { Avermelhada (Absorbância }=1,548 \mathrm{a} 550 \mathrm{~nm})\end{array}$ \\
\hline Fragrance / Odor & Characteristic / Característico \\
\hline
\end{tabular}

*Calculated using a Ford Cup viscometer from Gehaka (São Paulo, Brazil) and orifice $\mathrm{n}^{\mathrm{o}} 2$; The viscosity produced was the average of the values obtained, expressed in $\mathrm{mm}^{2} / \mathrm{s}$ or Centistokes $(\mathrm{cSt})(40) .{ }^{*}$ Calculated using a pycnometer. *Calculada utilizando-se viscosímetro Copo Ford da marca Gehaka (São Paulo, Brasil) e orifício número 2; A viscosidade produzida foi a média dos valores obtidos, expressa em $\mathrm{mm}^{2} / \mathrm{s}$ ou Centistokes $(\mathrm{cSt})(40)$. ${ }^{* *}$ Calculada utilizando-se um picnómetro.

Table 4 - Physico-chemical properties of shampoo samples in different storage times and temperature conditions

Tabela 4 - Propriedades físico-químicas das amostras de shampoo matizante em diferentes tempos de armazenamento e condições de temperatura

\begin{tabular}{|c|c|c|c|c|}
\hline $\begin{array}{l}\text { Temperature }\left(C^{\mathbf{o}}\right) / \\
\text { Temperatura }\left(C^{0}\right)\end{array}$ & $\begin{array}{l}\text { Time (days) / } \\
\text { Tempo(dias) }\end{array}$ & $\begin{array}{l}\text { Organoleptic characteristics } \\
\text { (color, odor, appearance) / } \\
\text { Características organolépticas } \\
\text { (cor, odor, aspecto) }\end{array}$ & pH & $\begin{array}{l}\text { Viscosity* }^{*}(\mathrm{cSt}) / \\
\text { Viscosidade }^{*}(\mathrm{cSt})\end{array}$ \\
\hline \multirow{4}{*}{$25 \pm 5^{\circ} \mathrm{C}$} & $\mathbf{0}$ & $\begin{array}{c}\text { No changes / } \\
\text { Sem alterações } \\
\end{array}$ & 6.07 & 10.64 \\
\hline & 30 & $\begin{array}{c}\text { No changes / } \\
\text { Sem alterações }\end{array}$ & 6.10 & 9.99 \\
\hline & 60 & $\begin{array}{c}\text { No changes / } \\
\text { Sem alterações }\end{array}$ & 5.80 & 10.89 \\
\hline & 90 & $\begin{array}{c}\text { No changes / } \\
\text { Sem alterações }\end{array}$ & 5.9 & 10.80 \\
\hline \multirow{4}{*}{$\begin{array}{c}42 \pm 2{ }^{\circ} \mathrm{C} \text { and } \\
75 \% \mathrm{UR}^{*}\end{array}$} & $\mathbf{0}$ & $\begin{array}{c}\text { No changes / } \\
\text { Sem alterações }\end{array}$ & 6.07 & 10.64 \\
\hline & 30 & $\begin{array}{c}\text { No changes / } \\
\text { Sem alterações }\end{array}$ & 5.80 & 10.70 \\
\hline & 60 & $\begin{array}{c}\text { No changes / } \\
\text { Sem alterações }\end{array}$ & 5.90 & 11.20 \\
\hline & 90 & $\begin{array}{l}\text { No changes / } \\
\text { Sem alterações }\end{array}$ & 5.90 & 10.11 \\
\hline
\end{tabular}

*Calculated using a Ford Cup viscometer from Gehaka (São Paulo, Brazil) and orifice $\mathrm{n}^{\circ} 2$; The viscosity produced was the average of the values obtained, expressed in $\mathrm{mm}^{2} / \mathrm{s}$ or Centistokes $(\mathrm{cSt})(40)$. **UR = relative humidity

*Calculada utilizando-se viscosímetro Copo Ford da marca Gehaka (São Paulo, Brasil) e orifício número 2; A viscosidade produzida foi a média dos valores obtidos, expressa $\mathrm{em}^{\mathrm{mm}}$ /s ou Centistokes $(\mathrm{cSt})(40)$.; **UR = humidade relativa 
Regarding the shampoo samples, no changes were observed during the period of the preliminary stability tests. In the accelerated stability studies, no significant organoleptic changes were observed with impairment of sensorial characteristics or in relation to $\mathrm{pH}$ and viscosity values, during the entire evaluated storage period (Table 4).

\section{Characterization of the body exfoliating cream}

The physical or mechanical exfoliation of the skin is superficial, since the active exfoliating agent does not interact with the internal layers of the skin. The exfoliating agent content based on polyethylene in cosmetic preparations may range from $0.05 \%$ to $12 \%(\mathrm{w} / \mathrm{w})$, depending on the type of product and particle size (15). Thus, the addition of $1 \%, 1.5 \%$, and $2 \%(\mathrm{w} / \mathrm{w})$ exfoliating granules were tested because they are the most commonly present in cosmetic products with exfoliating functions. The addition of $1.0 \%(\mathrm{w} / \mathrm{w})$ exfoliating granules was the most adequate from both visual and sensorial aspects, being chosen for the formulation of the body exfoliating cream.

The exfoliating body cream produced was characterized and subjected to the preliminary stability and accelerated stability tests. The quality evaluation of the body exfoliating cream included sensorial and physicochemical analyses (34), organoleptic characteristics, $\mathrm{pH}$ value, viscosity and scattering. The results obtained in these tests are displayed in Table 5.

Regarding the organoleptic characteristics of the body exfoliating cream, the formulation produced was macroscopically homogeneous, shiny, exhibiting white color and pleasant odor, with uniform distribution of the exfoliating granules. The viscosity, $\mathrm{pH}$, and spreadability parameters were adequate for a body cream and are important parameters for the consumer acceptance of the product (39). The spreadability and viscosity of semisolid preparations are quite variable depending on their constituents, form of preparation, and intended use (22).

Accelerated stability tests (centrifugation, heat stress, and freeze-thaw cycles) indicated good physical-chemical stability without creaming, flocculation, or coalescence phenomena.

The exfoliating body cream prepared had a $\mathrm{pH}$ value suitable for body use, which remained stable throughout the storage period. After 90 days of storage, the $\mathrm{pH}$ values showed a small decrease, but still remaining within the $\mathrm{pH}$ range considered suitable for a cosmetic product to be applied on the skin. Throughout the storage period studied, no changes were observed indicating loss of stability of the developed body exfoliating cream. The ela representa um fator sensorial importante para o consumidor $(36,37)$. No shampoo matizante formulado observou-se uma adequada formação de espuma, o que pode ser considerado um fator de qualidade positivo para o produto.

Não foram observadas quaisquer alterações durante o período de realização dos ensaios de estabilidade preliminar nas amostras de shampoo. Nos estudos de estabilidade acelerada não se observaram alterações organolépticas significativas com comprometimento das características sensoriais, em relação aos valores de $\mathrm{pH}$ e de viscosidade, durante todo o período de armazenamento avaliado (Tabela 4).

\section{Caracterização do creme corporal esfoliante}

A esfoliação física ou mecânica da pele é superficial, uma vez que o agente esfoliante ativo não interage sob a pele. Teores de agentes esfoliantes à base de polietileno em preparações cosméticas podem variar entre $0,05 \%$ a $12 \%(\mathrm{~m} / \mathrm{m})$, dependendo do tipo de produto e tamanho das partículas (15). Assim, testou-se a adição de $1 \%, 1,5 \%$ e $2 \%(\mathrm{~m} / \mathrm{m})$ de grânulos esfoliantes, por serem estes os teores mais vulgarmente presentes em produtos cosméticos com função esfoliante. A adição de $1,0 \%(\mathrm{~m} / \mathrm{m})$ de grânulos esfoliantes foi considerada a mais adequada tanto do ponto de vista visual como sensorial, sendo escolhida para a formulação do creme corporal esfoliante.

O creme corporal esfoliante produzido foi caracterizado e sujeito aos testes de estabilidade preliminar e de estabilidade acelerada. Os métodos de avaliação da qualidade do creme corporal esfoliante abrangeram análises sensoriais e físico-químicas (38), tendo sido avaliadas características organolépticas, $\mathrm{pH}$, viscosidade e espalhabilidade. Os resultados obtidos nestes testes podem ser encontrados na Tabela 5.

Em relação às características organolépticas do creme corporal esfoliante, a formulação apresentou-se macroscopicamente homogénea, brilhante, com coloração branca e odor agradável, com distribuição uniforme dos grânulos esfoliantes. Os parâmetros viscosidade, $\mathrm{pH}$ e espalhabilidade foram considerados adequados para um creme corporal, sendo parâmetros importantes para a aceitação do produto pelo consumidor (39). A espalhabilidade e viscosidade das preparações semisólidas são bastante variáveis dependendo dos seus constituintes, forma de preparação e uso intencionado (22).

Os testes de estabilidade acelerada (centrifugação, stress térmico e ciclos de congelação-descongelação) indicaram uma boa estabilidade físico-química com ausência dos fenômenos de cremeação, floculação e coalescência. 
Table 5 / Tabela 5 -Results obtained for the quality parameters of the exfoliating body cream produced with $1.0 \%(\mathrm{w} / \mathrm{w})$ of exfoliating granules obtained from the seeds of the fruits of the Jussara palm tree / Resultados obtidos para os parâmetros de qualidade do creme corporal esfoliante obtidos a partir das sementes dos frutos da palmeira Jussara.

\begin{tabular}{|c|c|}
\hline Parameter evaluated / Parâmetro avaliado & Results obtained / Resultados obtidos \\
\hline $\begin{array}{c}\text { Organoleptic characteristics / } \\
\text { Características organolépticas }\end{array}$ & $\begin{array}{c}\text { White color, shiny and homogeneous / } \\
\text { Coloração branca, brilhante e homogénea } \\
\text { Characteristic odor / Odor característico } \\
\text { Uniform distribution of the granules / } \\
\text { Distribuição uniforme dos grânulos }\end{array}$ \\
\hline $\mathrm{pH}$ & $5.950 \pm 0.012$ \\
\hline Viscosity* / Viscosidade* & $921 \pm 31.28 \mathrm{cP}$ \\
\hline Spreadability / Espalhabilidade & $36-42 \mathrm{~mm}^{2}$ \\
\hline
\end{tabular}

*Calculated using a Brookfield viscometer, model DV-I Prime, with spindle $\mathrm{n}^{\circ} 2$. Viscosity in this equipment was obtained in centipoise (cP) (40)

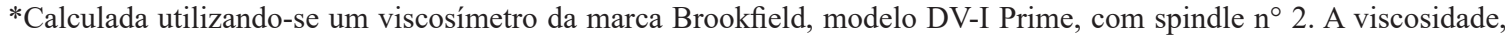
neste equipamento, foi obtida em centipoise (cP) (40)

Table 6 / Tabela 6 -Physico-chemical properties of exfoliating cream samples in different storage times and temperature conditions / Propriedades físico-químicas das amostras de shampoo matizante em diferentes tempos de armazenamento e condições de temperatura

\begin{tabular}{|c|c|c|c|c|}
\hline $\begin{array}{c}\text { Time (days) / } \\
\text { Tempo(dias) }\end{array}$ & $\begin{array}{c}\text { Organoleptic characteristics } \\
\text { (color, odor, appearance)/ } \\
\text { Características organolépticas } \\
\text { (cor, odor, aspecto) }\end{array}$ & $\mathbf{p H}$ & $\begin{array}{c}\text { Viscosity* (cP)/ } \\
\text { Viscosidade* (cP) }\end{array}$ & $\begin{array}{c}\text { Spreadability }\left(\mathbf{m m}^{2}\right) / \\
\left.\text { Espalhabilidade } \mathbf{( m m}^{2}\right)\end{array}$ \\
\hline $\mathbf{0}$ & $\begin{array}{c}\text { No changes / } \\
\text { Sem alterações }\end{array}$ & 5.95 & $921 \mathrm{cP} *$ & $42-34$ \\
\hline $\mathbf{3 0}$ & $\begin{array}{c}\text { No changes / } \\
\text { Sem alterações }\end{array}$ & 5.94 & $913 \mathrm{cP}$ & $42-35$ \\
\hline $\mathbf{6 0}$ & $\begin{array}{c}\text { No changes / } \\
\text { Sem alterações }\end{array}$ & 5.94 & $917 \mathrm{cP}$ & $42-35$ \\
\hline $\mathbf{9 0}$ & $\begin{array}{c}\text { No changes / } \\
\text { Sem alterações } \\
\text { No changes / } \\
\text { Sem alterações }\end{array}$ & 5.91 & $916 \mathrm{cP}$ & $42-36$ \\
\hline $\mathbf{0}$ & $\begin{array}{c}\text { No changes / } \\
\text { Sem alterações }\end{array}$ & 5.96 & $920 \mathrm{cP}$ & $42-36$ \\
\hline $\mathbf{3 0}$ & $\begin{array}{c}\text { No changes / } \\
\text { Sem alterações }\end{array}$ & 5.94 & $917 \mathrm{cP}$ & $42-35$ \\
\hline $\mathbf{6 0}$ & $\begin{array}{c}\text { No changes / } \\
\text { Sem alterações }\end{array}$ & 5.92 & $919 \mathrm{cP}$ & $42-35$ \\
\hline
\end{tabular}

*Calculated using a Brookfield viscometer, model DV-I Prime, with spindle $\mathrm{n}^{\mathrm{o}} 2$. Viscosity in this equipment was obtained in centipoise $(\mathrm{cP})(40) . * * \mathrm{UR}=$ relative humidity

*Calculada utilizando-se um viscosímetro da marca Brookfield, modelo DV-I Prime, com spindle ${ }^{\circ} 2$. A viscosidade, neste equipamento, foi obtida em centipoise (cP) (40).; **UR = humidade relativa 
results of the viscosity and spreadability were very consistent throughout the storage period, indicating that the cream prepared remained stable. Regarding the results obtained in the spreadability tests, it was observed that the values produced did not change significantly during the product storage period (Table 6).

\section{Conclusions}

The anthocyanin extract obtained from the fruits of Jussara palm tree showed a high content of anthocyanins and a high antioxidant capacity. Hence, the fruits of Jussara proved to be viable sources for the commercial exploitation of anthocyanins, with promising use in cosmetic products such as those formulated in the present research work. The use of a natural scrub is also very interesting as synthetic exfoliators are proving to be potent environmental contaminants. The shading shampoo exhibited adequate characteristics for the intended use and was stable during the stability tests performed. The body exfoliating cream integrating the granules obtained from the seeds of Jussara fruits showed excellent cosmetic properties and good stability.

The results of the study presented herein provide options for the use and valorization of the fruits of the Jussara palm tree.
O creme corporal esfoliante apresentou um valor de pH adequado para utilização corporal, tendo-se mantido estável durante todo o período de armazenamento. Após 90 dias de armazenamento, o valor de $\mathrm{pH}$ apresentou um pequeno decréscimo, mantendo-se no entanto dentro da gama de $\mathrm{pH}$ considerado adequado para um produto cosmético a ser aplicado sobre a pele. Durante todo o período de armazenamento estudado, não foram observadas alterações que indicassem perda de estabilidade do creme corporal esfoliante. Os resultados das determinações de viscosidade e espalhabilidade apresentaram-se bastante consistentes ao longo de todo o período de armazenamento, indicando que o creme preparado permaneceu estável. Em relação aos resultados obtidos nos testes de espalhabilidade, observou-se que os valores produzidos não variaram significativamente durante o período de armazenamento estudado (Tabela 6).

\section{Conclusões}

O extrato antocianínico obtido a partir dos frutos da palmeira Jussara apresentou elevado teor de antocianinas e elevada capacidade antioxidante. Assim, os frutos da Jussara provaram ser uma fonte viável para a exploração comercial de antocianinas, com utilização promissora em produtos cosméticos tais como os elaborados neste trabalho de investigação. O uso de um esfoliante de origem natural é também muito interessante, uma vez que os esfoliantes de origem sintética são potentes contaminantes ambientais.

O shampoo matizante apresentou características adequadas para o uso pretendido e mostrou-se estável durante os ensaios de estabilidade realizados. O creme corporal esfoliante integrando os grânulos obtidos a partir das sementes dos frutos de Jussara apresentou excelentes propriedades cosméticas e boa estabilidade. Os resultados do estudo aqui apresentado propicia opções para a utilização e valorização do fruto da palmeira Jussara. 


\section{Acknowledgements}

Project funding by Fundação de Amparo à Pesquisa do Estado de São Paulo (FAPESP, São Paulo, Brazil) (Ref. No. 2016/16641-3) is gratefully acknowledged. Project funding by FAPESP (Ref. No. 2018/05522-9 (Project PsaPhageKill)) in the form of a BPE fellowship granted to Victor M. Balcão is also hereby gratefully acknowledged. This work also received support from CNPq, National Council for Scientific and Technological Development Brazil, in the form of Research Productivity (PQ) fellowships granted to Victor M. Balcão (Refs. No. 306113/2014-7 and 308208/2017-0).

\section{Conflicts of interest}

The authors state that there are no financial or personal relationships that might be perceived as potential conflict of interests.

\section{Agradecimentos}

À Fundação de Amparo à Pesquisa do Estado de São Paulo (FAPESP, São Paulo, Brazil), pelo financiamento concedido para a realização de projeto de investigação (Ref. No. 2016/16641-3). O financiamento pela FAPESP (Ref. No. 2018/05522-9 (Projeto PsaPhageKill)) na forma de uma bolsa de investigação BPE concedida a Victor M. Balcão é também por este meio reconhecido. Este trabalho também recebeu suporte por parte do CNPq, Conselho Nacional de Desenvolvimento Científico e Tecnológico do Brasil, na forma de Bolsas de Produtividade em investigação (PQ) concedidas a Victor M. Balcão (Refs. No. 306113/2014-7 and 308208/2017-0).

\section{Conflitos de interesse}

Os autores declaram que não existem relações financeiras ou pessoais que possam ser vistas como potenciais conflitos de interesse. 


\section{References / Referências}

1. Ribeiro AS, Estanqueiro M, Oliveira MB, Lobo JMS. Main benefits and applicability of plant extracts in skin care products. Cosmetics 2015; 2(2):48-65.

2. Joshi LS, Pawa HA Herbal cosmetics and cosmeceuticals: an overview. Nat Prod Chem Res 2015; 3(2): 2-8.

3. Garbossa WAC, Campos PMBGM. Euterpe oleracea, Matricaria chamomilla, and Camellia sinensis as promising ingredients for the development of skin care formulations. Ind Crops Prod. 2016; 83: 1-10.

4. Daher C.C, Fontes I.S., Rodrigues, R.O., Damasceno, G.A.B., Soares, D.S., Aragão, C.F.S., Gomes, A.P.B. and Ferrari, M. Development of O/W creams containing Euterpe oleracea extract and evaluation of photoprotective efficacy. Braz J Pharm Sci 2014; 50(3): 639-52.

5. Gasparrini M, Forbes-Hernandez TY, Afrin S, Alvarez-Suarez JM, González-Paramàs AM, Santos-Buelga C, Bompadre, S., Quiles, J.L., Mezzett, B. and Giampieri, F. A pilot study of the photoprotective effects of straberry-based cosmetic formulations on human dermal fibroblasts. Int J Mol Sci 2015; 16(8):17870-84.

6. Brito ES, Araújo MCP, Alves RE, Carkeet C, Clevidence BA, Novotny JA. Anthocyanins present in selected tropical fruits: acerola, jambolão, jussara and guajuru. J Agri Food Chem 2007; 55(23):9389-94.

7. Vieira GS, Cavalcanti RN, Meireles MAA, Hubinger MD. Chemical and economic evaluation of natural antioxidant extracts obtained by ultrasound-assisted and agitated bed extraction from jussara pulp (Euterpe edulis). J Food Eng 2013; 119(2);196-204.

8. Cortez R., Luna-Vital DA, Margulis D, Mejia EG Natural pigments: stabilization methods of anthocyanins for food applications. Compr Rev Food Sci Food Safety 2017; 16(1): 180-98.

9. Miraje SY, Amlepatil NM, Sahoo AK, Mote GV. Anthocyanin extraction from winery waste material: a review. J Innov Pharm Biol Sci 2015; 2(2); 218-21.

10. Silva HR, Assis DC, Prada AL, Keita H, Amado JRR, Carvalho JCT. Euterpe oleracea Mart. (açai): an old known plant with a new perspective. Afr J Pharm Pharmacol 2016;10(46):995-1006.

11. Suganya K, Preethi PS, Suganya M, Nanthini AUR. Natural pigments in cosmetics - past to present. Int J Pharm Sci Bus Manage 2016; 4(6):7-14.

12. França SA, Dario MF, Esteves VB, Baby AR, Velasco MVR Types of hair dye and their mechanisms of action. Cosmetics 2015; 2(2):110-26.

13. Dias MFRG Hair cosmetics: an overview. Int J Trichology 2015; 7(1): 2-15.

14. Wright SL, Thompson RC, Galloway TS The physical impacts of microplastics on marine organisms: a review. Environ Pollut 2013; 178:483-92.

15. Gouin T, Avalo J, Brunning I, Brzuska K, Graaf J, Kaumanns J, Koning T, Meyberg M, Rettinger K, Schlatter H, Thomas J, Van Welie R, Wolf T Use of micro-plastic beads in cosmetic products in Europe and their estimated emissions to the North Sea environment. Int J Appl Sci. 2015; 3:40-6.

16. Bennett O, Hirst D. Microbeads and microplastics in cosmetic and personal care products. House of Commons Library 2017; 7510 (4): 1-17. Available from: https://researchbriefings.parliament.uk/ResearchBriefing/Summary/CBP-7510.

17. Rochman CM, Kross SM, Armstrong JB, Bogan MT, Darling ES, Green SJ, Smyth AR, Verissimo D. Scientific evidence supports a ban on microbeads. Environ Sci Technol. 2015; 49(18):10759-61.

18. Favaro, L. I. L.; Balcão, V. M.; Rocha, L. K. H.; Silva, E. C.; Oliveira Jr., J. M.; Vila, M. M. D. C.; Tubino, M. (2018) Physicochemical Characterization of a Crude Anthocyanin Extract from the Fruits of Jussara (Euterpe edulis Martius): Potential for Food and Pharmaceutical Applications, J. Braz. Chem. Soc. 29 (10): 2072-2088.

19. AOAC. Official methods of analysis of AOAC international 18th Edition, AOAC International, Maryland, 2005.

20. Prieto P, Pineda M, Aguilar M. Spectrophotometric quantification of antioxidant capacity through the formation of a phosphomolybdenum complex: specific application to the determination of vitamin E. Anal Biochem 1999; 269(2):337-41.

21. CLSI. Performance standards for antimicrobial disk susceptibility Tests: Approved Standard. 18 ed. NCCLS document M2-A8. Wayne, PA CLSI, 2003.

22. Ansel HC, Popovich NG, Allen JL. Ansel's pharmaceutical dosage forms and drug delivery system. 8 ed., Ed Lippincott Willians \& Wilkins, Philadelphia, 2005.

23. Brazil, National Agency of Sanitary Surveillance. Resolution of the Collegiate Board of Directors RDC $n^{\circ} 67$, of October 8, 2007. Provides on good practices of manipulation of the magistrate and official preparations for human use in pharmacies. DOU, $\mathrm{n}^{\circ}$ 195, 2007 October 9. Section 1. pp. 29-58, 2007.

24. SILVA LC, Vieira JPC, Silva LAC, Monteiro OS, Carmo LHA, Delineamento de formulações cosméticas com óleo essencial de Lippia gracilis Schum (Alecrim-de Tabuleiro) de origem amazônica. Rev Ciênc Farm Básica Apl 2015; 36(2): 319-326.

25. Proença KS, Roma RM, Oliveira RVM, Gonçalves MM, Vila MMDC. Avaliação da estabilidade de cremes empregando diferentes agentes de consistência. Rev Bras Farm 2006; 87(3):74-7.

26. Lima AJB, Corrêa AD, Saczk AA, Martins MP, Castilho RO. Anthocyanins, pigment stability and antioxidant activity in jabuticaba. Rev Bras Frut. 2011; 33(3):877-87.

27. Patil N, Datar A. Extraction, stability and separation of anthocyanins of Ixora coccinea Linn. Int J Pharm Pharm Sci 2015; 7(3):198-202.

28. Schulz M, Borges GSC, Gonzaga LV, Seraglio SK., Olivo IS, Azevedo MS, Nehring P, Gois JS, Almeida TS, Vitali L, Spudeit DA, Micke GA, Borges DLG, Fett R. Chemical composition, bioactive compounds and antioxidant capacity of juçara fruit (Euterpe edulis Martius) during ripening. Food Res Int 2015; 77: $125-31$

29. Schulz M, Borges GSC, Gonzaga LV, Costa ACO, Fett R. Juçara fruit (Euterpe edulis Mart): sustainable exploitation of a source of bioactive compounds. Food Res Int 2016; 89:14-26.

30. Borges GS, Vieira FGK, Copetti C, Gonzaga LV, Zambiazi R C, Mancini Filho J, Fett R. Chemical characterization, bioactive compounds, and antioxidant capacity of jussara (Euterpe edulis) fruit from the Atlantic Forest in southern Brazil. Food Res Int 2011; 44(7): 2128-33.

31. Chang M. Reducing microplastics from facial exfoliating cleansers in wastewater through treatment versus consumer product decisions. Mar Pollut Bull $2015 ; 101(1): 330-33$.

32. Abu-Dief EE. Morphological changes of the skin following microdermabrasion and chemical peeling. Ann Histol Surg Pathol 2017; 1(1): 3-4.

33. Sandriani Y, Nugroho B H, Tsani SFI, Syukri Y. (2017). Formulation of lipbutter using Red Dragon fruit extract (Hylocereus costaricensis) as natural dyes with various oil phase concentration. Int J Res Sci 2017; 3(3): 6-8

34. Pipattanamomgkol P, Lourith N, Kanlayavattanakul M. (2018). The natural approach to hair dyeing product with Cleistocalyx nervosum var. paniala. Sustain Chem Pharm 2018; 8: 88-93.

35. Rose P M, Cantrill V, Benohoud M, Tidder A, Rayner CM, Blackburn RS. Application of anthocyanins from blackcurrant (Ribes nigrum 1.) fruit waste as renewable hair dyes. J. Agric. Food Chem. 2018: 66, 6790-6798.

36. Kumar A, Mali RR. Evaluation of prepared shampoo formulations and to compare formulated shampoo with marketed shampoos. Int J Pharm Sci Rev Res 2010; 3(1): 120-6.

37. Molvovan M, Parauan S. Cosmetic evaluation of some commercial shampoos. Clujul Med 2012; 85(3): 378-83.

38. Brazil, National Agency of Sanitary Surveillance. Guide to quality control of cosmetic products: an approach to physical and chemical testing. 2 ed, Anvisa, Brasília, 2008.

39. Montenegro L, Rapisarda L, Ministeri C, Puglisi G. Effects of lipids and emulsifiers on the physicochemical and sensory properties of cosmetic creams containing vitamin E. Cosmetics2015; 2(1): 35-47.

40. Farmacopeia Brasileira. 5a ed, Anvisa, Brasilia, 2010. 